\title{
OPEN Unique current connecting Southern and Indian Oceans identified from radium distributions
}

\author{
Mutsuo Inoue ${ }^{1 \bowtie}$, Shotaro Hanaki ${ }^{1}$, Hiroaki Kameyama ${ }^{1}$, Yuichiro Kumamoto ${ }^{2} \&$ \\ Seiya Nagao ${ }^{1}$
}

We examined the spatial variations in ${ }^{226} \mathrm{Ra}$ and ${ }^{228} \mathrm{Ra}$ (activities) concentrations from the surface to a depth of $830 \mathrm{~m}$ in the Indian and Southern Oceans from December 2019 to January 2020.

${ }^{226} \mathrm{Ra}$ concentrations at the surface increased sharply from $30^{\circ} \mathrm{S}$ to $60^{\circ} \mathrm{S}$ along a $\sim 55^{\circ} \mathrm{E}$ transect $(1.4-2.9 \mathrm{mBq} / \mathrm{L})$, exhibiting small vertical variations, while ${ }^{228} \mathrm{Ra}$ decreased southward and became depleted in the Southern Ocean. These distributions indicated the ocean-scale northward lateral transport of ${ }^{226} \mathrm{Ra}$-rich and ${ }^{228} \mathrm{Ra}$-depleted currents originating from the Antarctic Circumpolar Current (ACC). ${ }^{226} \mathrm{Ra}$ concentrations indicated that the fractions of the ACC at depths of $0-800 \mathrm{~m}$ decreased from 0.95 to 0.14 between $60^{\circ} \mathrm{S}$ and $30^{\circ} \mathrm{S}$. The ACC fractions in the subantarctic western Indian Ocean were higher than those previously reported in the eastern Indian region, indicating preferential transport of the ACC. The fractions obtained were approximately equivalent to those in the western Indian Ocean in the 1970s. This could be attributed to the minimal southward shift of the polar front due to global warming over the last 50 years.

The Antarctic Circumpolar Current (ACC) in the Southern Ocean $\left(>\sim 60^{\circ} S\right)$ is the largest eastward current in the global ocean, surrounding Antarctica. The strong ACC continually connects the Pacific, Atlantic, and Indian Oceans ${ }^{1-3}$. Therefore, this current plays an essential role in the global transport of biomass, nutrients, and pollutants. Additionally, in the subantarctic Indian and Southern Oceans, circulations are unique, with ocean-scale lateral current circulations occurring in the upper, intermediate, deep, and bottom layers ${ }^{4-6}$. The northward lateral currents, originating from the ACC, transport materials from the Southern to Indian Ocean, as well as to the Pacific and Atlantic Oceans, with different transport patterns in each ocean ${ }^{7-9}$. Furthermore, in the Southern Ocean, decadal variability in the Antarctic Polar Front has been recorded, reflecting the influence of climatic changes ${ }^{10,11}$. Therefore, the effects of the recent rapid global warming on ocean circulations are a major concern in marine environments.

Previous studies have investigated the current systems in this area using chemical tracers, such as chlorofluorocarbons (CFCs) and anthropogenic radionuclides ${ }^{7,12-14}$, as well as physical observations ${ }^{6}$. Additionally, natural and soluble radium isotopes such as ${ }^{226} \mathrm{Ra}$ (half-life: 1600 years) and ${ }^{228} \mathrm{Ra}$ (half-life: 5.75 years) are useful tracers for studying current circulation systems. ${ }^{226} \mathrm{Ra}$ in seawater columns is supplied from ${ }^{230} \mathrm{Th}$ in the bottom and coastal sediments (and settling particles), owing to its long half-life. The gradients of ${ }^{226} \mathrm{Ra}$ (activities) concentrations in water columns have been used to assess the vertical circulation in the global oceans and marginal seas ${ }^{15}$. Spatial variations in ${ }^{228} \mathrm{Ra}$ concentrations revealed the lateral circulation of surface seawater affected the coastal and shallow shelf sediments and the subsequent convection ${ }^{16}$. The variations of ${ }^{228} \mathrm{Ra}$ concentrations provide implications for the circulation patterns of soluble natural materials and artificial contaminants, such as the radiocesium derived from 2011 Fukushima Dai-ichi Nuclear Power Plant accident ${ }^{17,18}$, in various oceans and seas. Furthermore, the spatial distribution of ${ }^{228} \mathrm{Ra}$ concentrations, particularly at the surface, can potentially predict the transport patterns of soluble contaminants.

${ }^{226} \mathrm{Ra}$ and ${ }^{228} \mathrm{Ra}$ concentrations were primarily examined in the Indian and Southern Oceans from the late $1960 \mathrm{~s}^{19-23}$, particularly during the expedition of the Geochemical Ocean Sections Study (GEOSECS) conducted from December 1977 to April 1978. The spatial distributions of ${ }^{226} \mathrm{Ra}$ and ${ }^{228} \mathrm{Ra}$ concentrations showed different

${ }^{1}$ Low Level Radioactivity Laboratory, Kanazawa University, Wake O-24, Nomi, Ishikawa 923-1224, Japan. ${ }^{2}$ Research and Development Center for Global Change, Japan Agency for Marine-Earth Science and Technology, 2-15 Natushima-cho, Yokosuka, Kanagawa 237-0061, Japan. ${ }^{\circledR e m a i l: ~ i 247811 @ s t a f f . k a n a z a w a-u . a c . j p ~}$ 
features in the subtropical and subantarctic Indian and Southern Oceans, indicating unique and ocean-scale current circulations ${ }^{24-27}$ (and the biological scavenging of ${ }^{226} \mathrm{Ra}$ ) ${ }^{28}$. This study examined the spatial distributions of ${ }^{226} \mathrm{Ra}$ and ${ }^{228} \mathrm{Ra}$ concentrations at depths of $10-830 \mathrm{~m}$ from the northwestern Indian Ocean to the Southern Ocean and obtained a comprehensive understanding of temporal (over the last 50 years) and ocean-scale spatial variations (between the western and eastern Indian Ocean and the Southern Ocean), incorporating the results from previous studies ${ }^{19-27}$. Furthermore, it clarified ocean-scale current circulations in this area, focusing on the waters connecting the Southern and southern Indian Oceans.

\section{Results}

Characteristics of current layers. Surface salinity along the expedition route and sampling sites for MR19-18-141 waters are shown in Fig. 1a ${ }^{29}$.@@Cross-sectional observations of salinity and dissolved oxygen (DO) are presented in Fig. 1b,c, respectively. Water columns at sites MR19-18 and -49 contained high-salinity (>34.5) North Indian Central Water formed by subduction at the subtropical front ${ }^{4}$, which was covered with low-salinity upper-layer waters from the surface to depths of 50-150 m (Fig. 1b). In contrast, low-salinity southward currents (e.g., Antarctic Intermediate Water; AAIW) had a lesser effect on site MR19-4927.

The physicochemical characteristics above a depth of $\sim 1000 \mathrm{~m}$ changed drastically northward of site MR19104. The salinity of the water columns at sites MR19-104 and -141 was remarkably lower $(<34.7)$ than that at site MR19-73 (34.5-35.5). Based on the salinity and DO profiles, water columns from depths of $>100-800 \mathrm{~m}$ at sites MR19-73 and -104 predominantly comprised the Subantarctic Mode Water (SAMW) and AAIW, which is formed via the convection of Antarctic Surface Water, existing between the upper layer and Upper Circumpolar Deep Water (UCDW) 6,30,31. The UCDW and Lower Circumpolar Deep Water (LCDW), which may be characterized as the oxygen-minimum and salinity-maximum layers, respectively, spread northward from Antarctica. These layers occupied depths of 200-700 m and 700-1200 $\mathrm{m}$ at site MR19-141 and exhibited convective behavior at depths of $\sim 1000-2000 \mathrm{~m}$ and $\sim 2000-3000 \mathrm{~m}$ at sites MR19-73 and -104, respectively. The major components of the water columns at sites MR19-73, -104, and -141 (depth of 0-800 m) were the SAMW, AAIW, and UCDW, respectively.

Surface ${ }^{226} \mathrm{Ra}$ and ${ }^{228} \mathrm{Ra}$ profiles. The lateral (surface) profiles of ${ }^{226} \mathrm{Ra}$ and ${ }^{228} \mathrm{Ra}$ concentrations in the Indian and Southern Oceans are shown in Fig. 2, along with data from previous studies ${ }^{20-25}$. At the surface, ${ }^{226} \mathrm{Ra}$ concentrations along the coasts of Southeast Asia were higher than those in the ambient areas; it decreased towards offshore areas (Fig. 2a). In contrast, the concentrations gradually increased from $>\sim 40^{\circ} \mathrm{S}$ to the Southern Ocean. Similarly, the ${ }^{226} \mathrm{Ra}$ concentrations of surface waters were $\sim 1.5 \mathrm{mBq} / \mathrm{L}$ at sites MR19-18 and -49 ; it increased sharply from 1.4 to $2.9 \mathrm{mBq} / \mathrm{L}$ between sites MR19-73 and MR19-141.

The ${ }^{228} \mathrm{Ra}$ concentrations at the surface along the coasts of Southeast Asia were remarkably high $(5-10 \mathrm{mBq} / \mathrm{L})$, overlapping with the high- ${ }^{226} \mathrm{Ra}$ concentration areas, and decreased sharply towards the offshore, in the equatorial-subtropical area ${ }^{21-23}$ (Fig. 2b). Owing to the short half-life of ${ }^{228} \mathrm{Ra}$, high concentrations of this isotope can be attributed to the mixing of seawaters that have been in contact with the shallow continental shelf and coastal sediments, as observed in the East China Sea ${ }^{32,33}$. In this study, the high ${ }^{228} \mathrm{Ra}$ concentrations were predominantly ascribed to the continual supply of ${ }^{228} \mathrm{Ra}$ from the coasts of Southeast Asia. Subsequently, ${ }^{228} \mathrm{Ra}$ spread to the surrounding areas because of the southwestward monsoon currents, particularly in January ${ }^{34}$. Thus, the ${ }^{228} \mathrm{Ra}$ in surface waters at sites MR19-18 and $-49(1.8$ and $1.2 \mathrm{mBq} / \mathrm{L}$, respectively) could be attributed to the transport of the southward surface waters; their concentrations further decreased from site MR19-73 to -141 $(0.2$ to $<0.1 \mathrm{mBq} / \mathrm{L})$.

Vertical ${ }^{226} \mathrm{Ra}$ and ${ }^{228} \mathrm{Ra}$ profiles. The vertical profiles of the ${ }^{226} \mathrm{Ra}$ and ${ }^{228} \mathrm{Ra}$ concentrations are shown in Figs. 3 and 4, respectively. The profiles of ${ }^{226} \mathrm{Ra}$ concentrations showed three different features in the equatorial-monsoonal and subtropical Indian Ocean (northern side of $\sim 20^{\circ} \mathrm{S}$ ), subantarctic Indian Ocean $\left(20-60^{\circ} \mathrm{S}\right)$, and Southern Ocean (southern side of $\left.\sim 60^{\circ} \mathrm{S}\right)$ in both the western $\left(<90^{\circ} \mathrm{E}\right)$ and eastern sections $\left(>90^{\circ} \mathrm{E}\right)$. In the equatorial-subtropical area, the ${ }^{226} \mathrm{Ra}$ concentrations gradually increased with depth, in both the western ${ }^{25}$ and eastern Sections ${ }^{22}$, as well as in the Pacific Ocean in both hemispheres ${ }^{15}$, Sea of Japan ${ }^{16}$, and Bering Sea ${ }^{35}$. Similarly, the ${ }^{226} \mathrm{Ra}$ concentrations at sites MR19-18 and -49 increased from 1.5 to $3.5 \mathrm{mBq} / \mathrm{L}$ between water depths of 10 and $830 \mathrm{~m}$. At sites MR19-73 and -104 in the subantarctic area, minor vertical variations in ${ }^{226} \mathrm{Ra}$ concentrations were observed with depth, particularly below $100 \mathrm{~m}$, relative to those at sites MR19-18 and -49. The concentrations at site MR19-104 were remarkably higher than those at site MR19-73 (2.2-2.7 vs. 1.4-1.6 mBq/L), accompanying the lower salinity at site MR19-104 (Fig. 1b). The ${ }^{226} \mathrm{Ra}$ concentrations at sites MR19-73 and -104 were similar to those recorded at nearby sites in 1978 (sites 427-428 and 429, respectively) ${ }^{25}$. In contrast, the ${ }^{226} \mathrm{Ra}$ concentrations were higher than those at similar latitudes in the eastern Indian Ocean ${ }^{20,22}$. The ${ }^{226} \mathrm{Ra}$ concentrations in the Southern Ocean were considerably higher than those in the subantarctic Indian Ocean at all sites and depths. Although the variations in ${ }^{226} \mathrm{Ra}$ concentrations were small in the Southern Ocean, as well as in the western Pacific and eastern Atlantic Sections ${ }^{28,36}$, the concentrations exhibited spatial heterogeneity despite the vigorous lateral circulation of the ACC. The ${ }^{226} \mathrm{Ra}$ concentrations at site MR19-141 were approximately equal to those recorded at the nearest sites 430 and 431, which were closer to the concentrations recorded at the same depth in Antarctica (64 $11^{\prime}$ S) in $1978^{24}$, and higher than those recorded in the eastern Indian Section ${ }^{20}$. The ${ }^{228} \mathrm{Ra}$ concentrations at sites MR19-18 and -49 decreased sharply from the surface to a depth of $100 \mathrm{~m}$, exhibiting stratification at a depth of $\sim 100 \mathrm{~m}$ (Fig. 4). Such vertical profiles have commonly been observed in the northeastern Indian Ocean ${ }^{22}$ as well as in other oceans ${ }^{15}$ and marginal seas ${ }^{16}$. In addition, the ${ }^{228}$ Ra concentrations in MR19-18 and -49 waters were lower than those in the waters of the eastern Indian Ocean ${ }^{22}$, reflecting a smaller contribution of coastal or shallow shelf waters. Furthermore, the concentrations and vertical gradient of ${ }^{228} \mathrm{Ra}$ at 


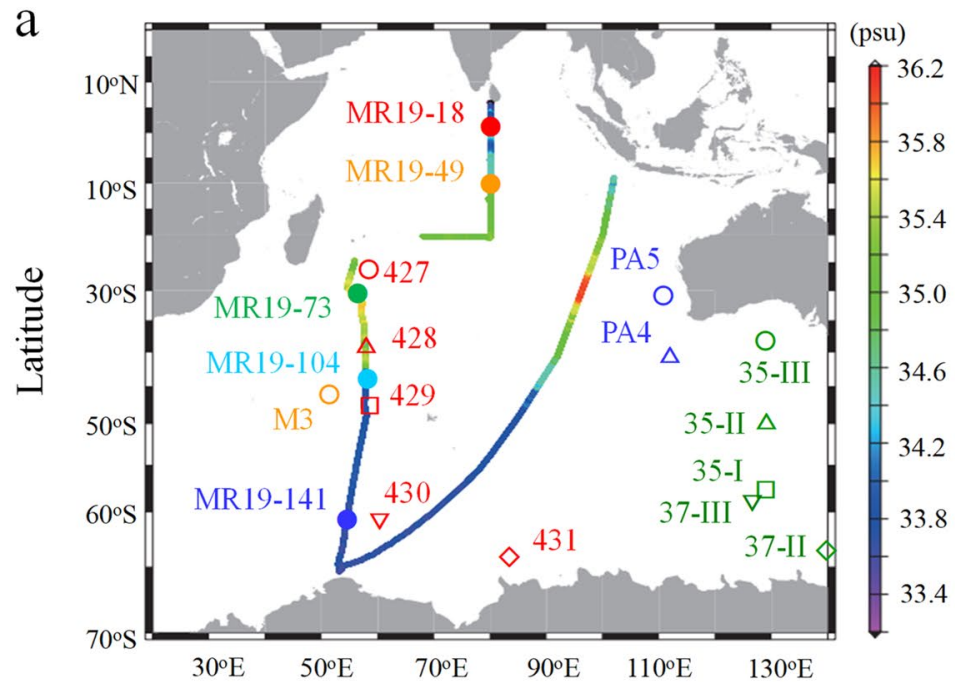

Longitude
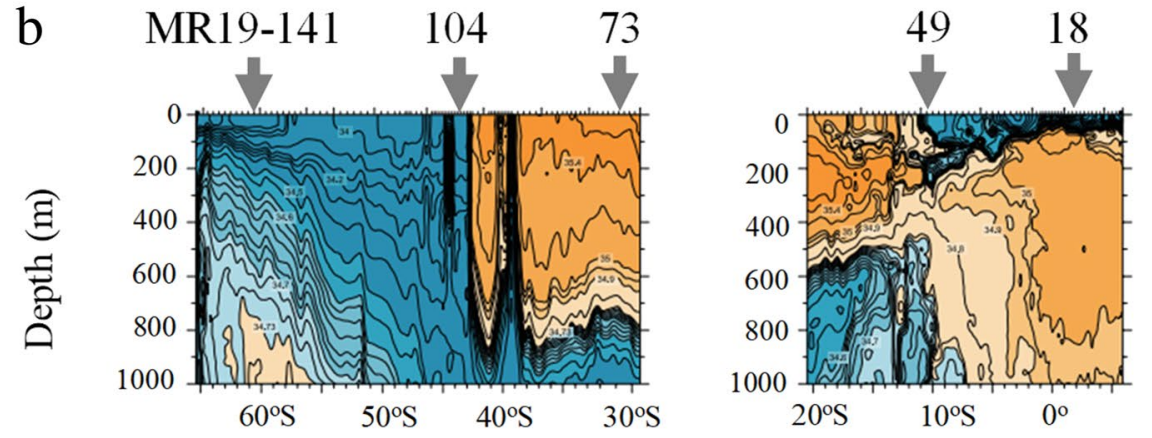

(psu)
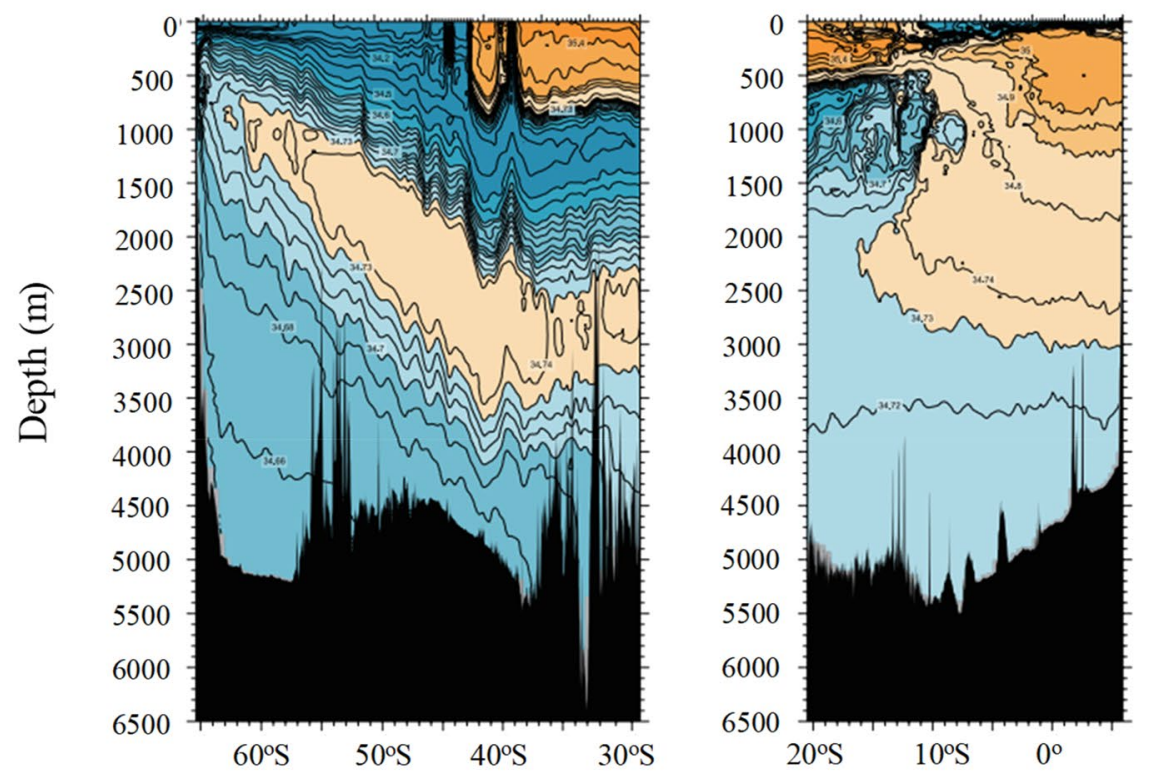

Latitude

Latitude

Figure 1. (a) Surface salinity along with sampling sites of the MR19-18-141 seawaters in the Indian and Southern Oceans, with key sites from previous studies (sites 35 and 37 in 1968-1969 ${ }^{20}, 427-431$ in 1977$1978^{24,25}$, PA4 and PA5 in $1996^{22}$, and M3 in $2005^{19}$ ), and cross-sectional views of b) salinity and c) dissolved oxygen, along the R/V Mirai expedition route ${ }^{29}$. The figures were drawn using the Generic Mapping Tools ver. 4.1.1 (https://www.generic-mapping-tools.org/). 


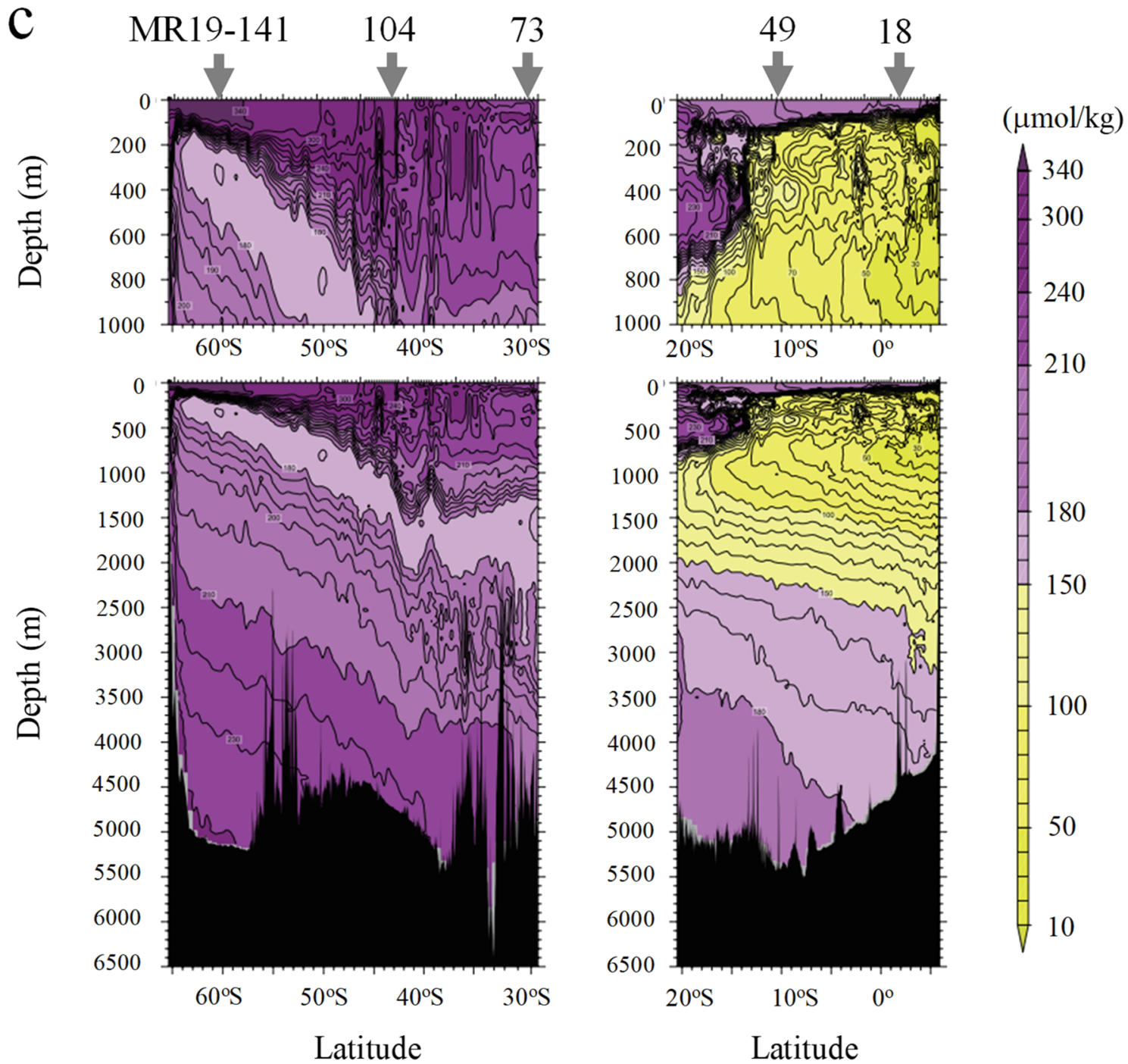

Figure 1. (continued)

site MR19-73 in the subantarctic area were remarkably lower than those at sites MR19-18 and -49; the concentrations below a depth of $\sim 100 \mathrm{~m}$ were between those observed at sites MR19-49 and -104 . The concentrations of ${ }^{228} \mathrm{Ra}$ supplied from the Antarctic continental shelf were high along the coast of the Weddell Sea $(\sim 4 \mathrm{mBq} / \mathrm{L}$ at $20 \mathrm{~m}$ depth) and decreased sharply offshore ${ }^{37}$. The ${ }^{228} \mathrm{Ra}$ concentrations in the waters from site MR19-141 in the Southern Ocean area were the lowest in the study area, at all depths, as observed at the same latitude in the Weddell Sea $(<0.1 \mathrm{mBq} / \mathrm{L})$.

${ }^{226} \mathrm{Ra}$ versus ${ }^{228} \mathrm{Ra}$ concentrations. Figure 5 shows the concentrations of ${ }^{226} \mathrm{Ra}$ plotted against those of ${ }^{228} \mathrm{Ra}$ for MR19 waters, along with previous data from the Indian and Southern Ocean ${ }^{19,21-23}$. The seasonal variations in ${ }^{228} \mathrm{Ra}$ and ${ }^{226} \mathrm{Ra}$ concentrations, particularly in the northeastern Indian Ocean, were unclear (e.g., due to monsoon currents) ${ }^{34}$; however, the concentrations recorded at the surface from January to April exhibited a positive correlation (Fig. 5a). This predominantly reflects the supply of ${ }^{226} \mathrm{Ra}$ and ${ }^{228} \mathrm{Ra}$ from shallow shelf and coastal sediments along the coasts of Southeast Asia. However, surface waters with high ${ }^{226} \mathrm{Ra}$ concentrations at sites MR19-73, -104 , and -141 and at a few sites in the subantarctic Indian Ocean ${ }^{23}$ exhibited the minimum ${ }^{228} \mathrm{Ra}$ concentrations.

The ${ }^{226} \mathrm{Ra}$ concentrations $(<2 \mathrm{mBq} / \mathrm{L})$ of waters at site MR19-73, including the eastern area (sites PA4 and PA5) ${ }^{22}$, above depths of $800 \mathrm{~m}$ exhibited a negative correlation with ${ }^{228} \mathrm{Ra}$ concentrations (Fig. $5 \mathrm{~b}$ ). However, the waters in the eastern area, particularly at depths of 5 and $50 \mathrm{~m}$ at site PA5, reflect the contribution of ${ }^{228} \mathrm{Ra}$ rich surface layer waters (Fig. 4). The ${ }^{228} \mathrm{Ra}$ concentrations in samples from sites MR19-104 and -141 with high ${ }^{226} \mathrm{Ra}$ concentrations $(>2 \mathrm{mBq} / \mathrm{L})$, as well as a site in the western area $(\sim 0.01 \mathrm{mBq} / \mathrm{L} \text { at M3 })^{19}$, were below the detection limit $(<0.03 \mathrm{mBq} / \mathrm{L})$. Additionally, low ${ }^{228} \mathrm{Ra}$ concentrations at site MR19-141 indicated that the contribution of waters affected by the ${ }^{228} \mathrm{Ra}$-rich continental slopes and coastal sediments along Antarctica was minimal. Additionally, the transport of waters from the Antarctic continental shelf to the offshore area was slow $(1.5 \text { years })^{37}$. Based on the spatial distributions of ${ }^{228} \mathrm{Ra}$ and ${ }^{226} \mathrm{Ra}$ concentrations (Figs. 3 and 4 ), water columns at sites MR19-18 and -49 were similar to those typically observed in open oceans ${ }^{15}$ and marginal seas ${ }^{16,35}$. In 

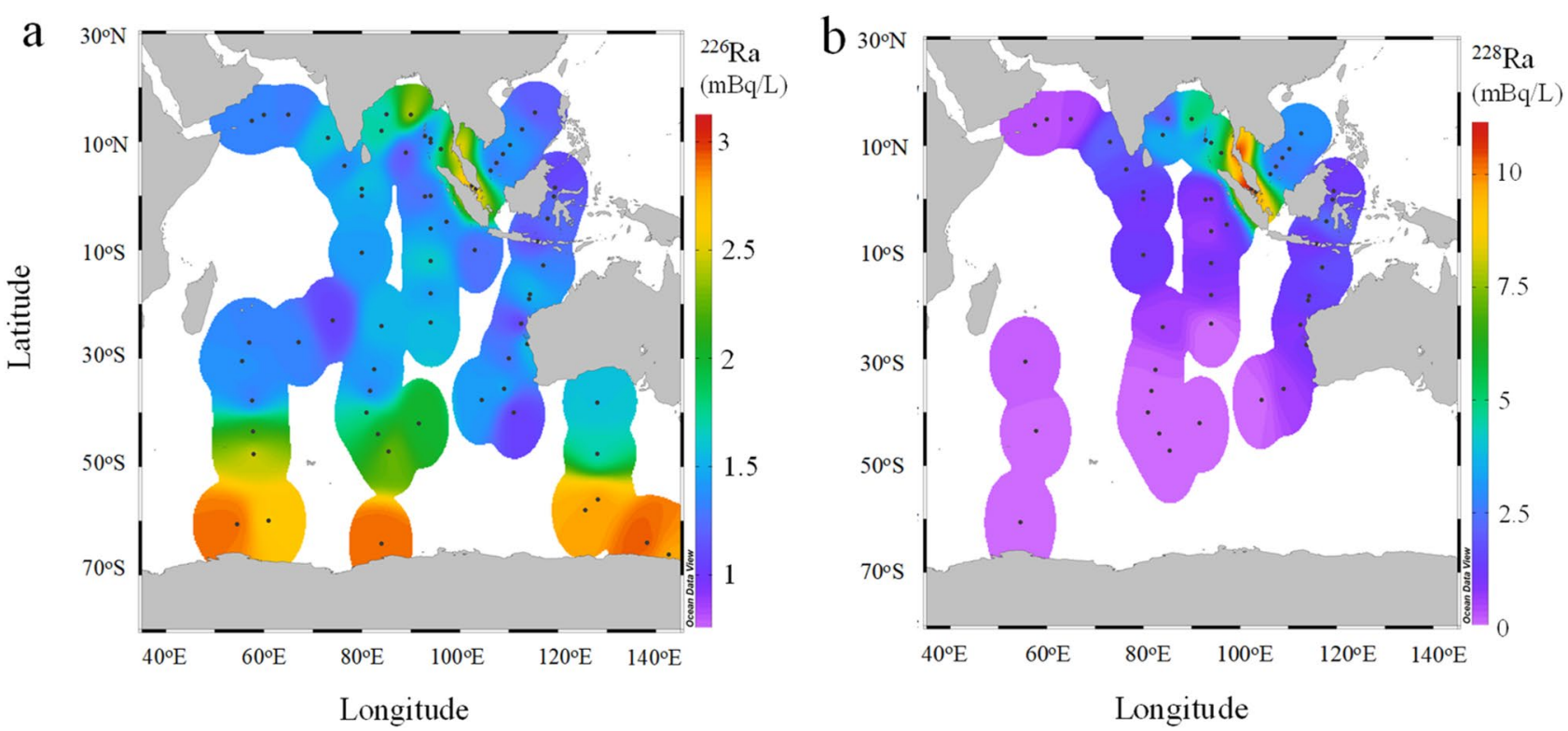

Figure 2. Lateral profile (depth $\leq 10 \mathrm{~m}$ ) of $(\mathbf{a}){ }^{226} \mathrm{Ra}$ and $(\mathbf{b}){ }^{228} \mathrm{Ra}$ concentrations (January-April) in the Indian and Southern Oceans, along with data from previous studies ${ }^{20-25}$. The map in this figure was drawn using Ocean Data View ver. 5.5.1 (http://odv.awi.de).

contrast, the spatial distributions of ${ }^{228} \mathrm{Ra}$ and ${ }^{226} \mathrm{Ra}$ concentrations at sites MR19-73, -104 , and -141 could be explained based on different current circulation systems.

\section{Discussion}

Figure 6 shows the ${ }^{226} \mathrm{Ra}$ concentrations of MR19 waters plotted against the potential density, along with previously reported data form the Indian and Southern Oceans ${ }^{20,24,25}$.

The ${ }^{226} \mathrm{Ra}$ concentrations of the upper-layer waters (10-100 $\mathrm{m}$ depth) at sites MR19-73, -104, and -141 likely exhibit a positive correlation with density, showing a less-steep slope $\left(n=9 ; r^{2}=0.87\right)$, than those at a depth $>100 \mathrm{~m}$. This indicates the mixing of the southward upper-layer currents, such as the subantarctic surface water $\left(\sim 1.5 \mathrm{mBq} / \mathrm{L}\right.$ for ${ }^{226} \mathrm{Ra}$ and $\left.\sim 25 \sigma_{\theta}\right)$. Therefore, it is inferred that the intrusion of the southward upper currents shifted the density and ${ }^{226} \mathrm{Ra}$ concentrations of water at depths of $0-100 \mathrm{~m}$ to lower sides.

Moreover, the ${ }^{226} \mathrm{Ra}$ concentrations in MR19 waters, particularly at depths of $>100-800 \mathrm{~m}$ at sites MR19-73, -104 , and -141 , were positively correlated with density $\left(n=12 ; \mathrm{r}^{2}=0.94\right)$. The ${ }^{226} \mathrm{Ra}$ concentrations gradually increased with depth in the bottom waters in the subtropical area, reflecting the supply of ${ }^{226} \mathrm{Ra}$ from the bottom sediments ${ }^{25}$; however, the concentrations were approximately constant below $1000 \mathrm{~m}$ in the subantarctic and Southern Oceans, even in the deep and bottom waters ${ }^{20,24}$. Based on the salinity and DO features (Fig. 1b,c), the water columns at sites MR19-73 and -104 are strongly stratified into the SAMW (26.5-26.8 $\left.\sigma_{\theta}\right)$ and AAIW $\left(27.0-27.3 \sigma_{\theta}\right)$, respectively, which disrupts the intense vertical mixing between these layers. Additionally, the ${ }^{226} \mathrm{Ra}$ concentrations of MR19 waters were two orders of magnitude higher than those of the reactive and parent ${ }^{230} \mathrm{Th}^{38}$; this indicates that ${ }^{226} \mathrm{Ra}$ is largely supplied from bottom and coastal sediments. Therefore, high ${ }^{226} \mathrm{Ra}$ concentrations and small vertical variations at site MR19-104 can be explained by the lateral transport of ${ }^{226} \mathrm{Ra}-$ rich waters rather than the upwelling of ${ }^{226} \mathrm{Ra}$ from the LCDW. The ${ }^{226} \mathrm{Ra}$-rich waters at MR19-141 in the Southern Ocean are mainly from UCDW $\left(\sim 27.6 \sigma_{\theta}\right)$, which plays a key role in increasing the ${ }^{226} \mathrm{Ra}$ concentrations of water columns at sites MR19-104 and -73.

Water column inventories (depth of $0-800 \mathrm{~m}$ ) of ${ }^{226} \mathrm{Ra}$ concentrations in the subantarctic Indian and Southern Oceans are plotted against latitude in Fig. 7 and compared with the values from previous studies ${ }^{19,20,22,24,25}$. The inventories increased sharply from site MR19-73 $\left(1205 \mathrm{~Bq} / \mathrm{m}^{2}\right)$ to MR19-141 (2550 Bq/m²) via site MR19-104 $\left(1900 \mathrm{~Bq} / \mathrm{m}^{2}\right)$. Inventories at sites MR19-73 and -104 in the subarctic area were evidently similar to those obtained at nearby sites in 1978 (sites 427-428 and 429, respectively) ${ }^{25}$. In contrast, the inventories decreased from the western Indian Ocean to offshore western Australia in the eastern Indian Ocean $\left(850 \mathrm{~Bq} / \mathrm{m}^{2}\right.$ at PA4 and $940 \mathrm{~Bq} /$ $\mathrm{m}^{2}$ at PA5) ${ }^{22}$. Combined with the high ${ }^{228} \mathrm{Ra}$ concentrations (Figs. $2 \mathrm{~b}$ and 4 ), the low inventories of ${ }^{226} \mathrm{Ra}$ at sites PA4 and PA5 can be attributed to the intrusion of southward currents with high ${ }^{228} \mathrm{Ra}$ and low ${ }^{226} \mathrm{Ra}$ concentrations (e.g., the Leeuwin Current) ${ }^{39}$. Furthermore, the inventory yielded a higher value at site MR19-104 than that at similar latitudes in southern Australia (1426 and $1616 \mathrm{~Bq} / \mathrm{m}^{2}$ at sites EL35-II and -III, respectively $)^{20}$. Such wide variations in the ${ }^{226} \mathrm{Ra}$ inventories, particularly from $30^{\circ} \mathrm{S}$ to $50^{\circ} \mathrm{S}$, indicate different transport patterns of ACC from the Southern Ocean to the western and eastern Indian Oceans.

The salinity at site MR19-141 in the Southern Ocean was at the same level as that at site 430, except for a lower value above a depth of $\sim 50 \mathrm{~m}^{40}$, indicating a larger contribution from Antarctic water. High-density $\left(>27 \sigma_{\theta}\right)$ and high- ${ }^{226} \mathrm{Ra}$ features in the upper-layer waters at site MR19-141, which are equivalent to those at sites 430 and 431 

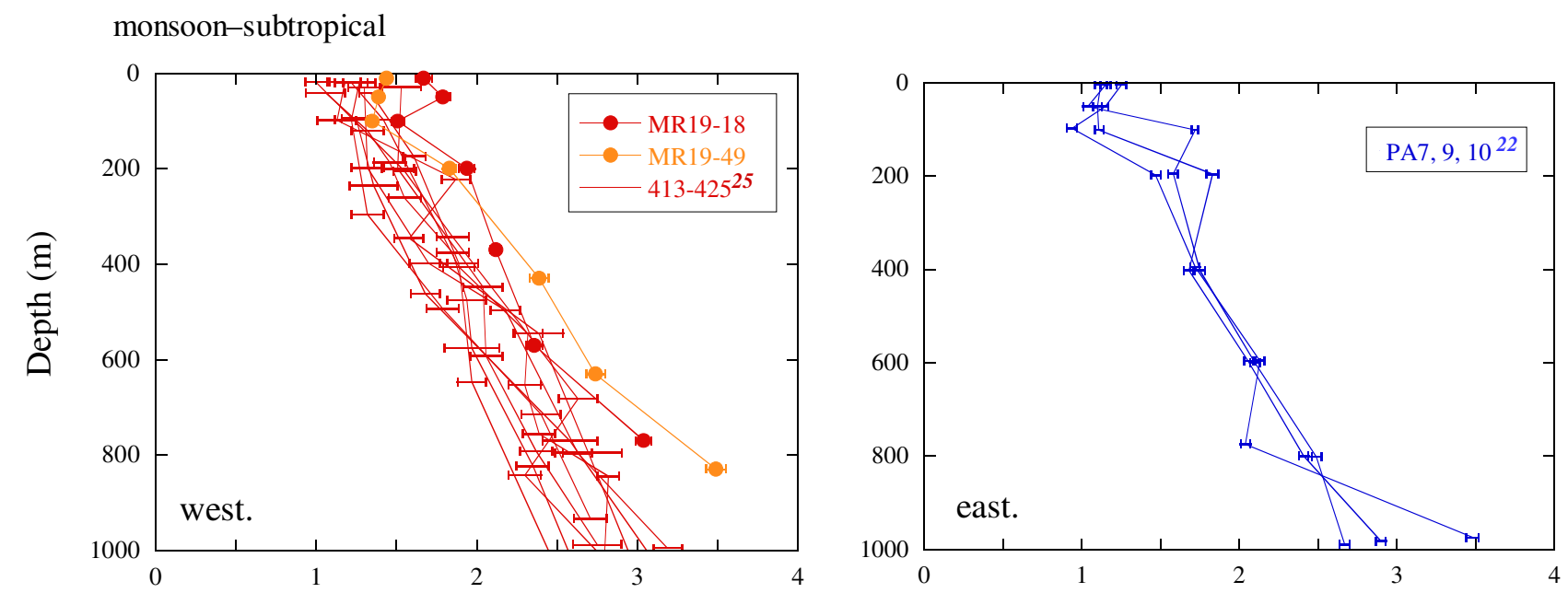

subantarctic
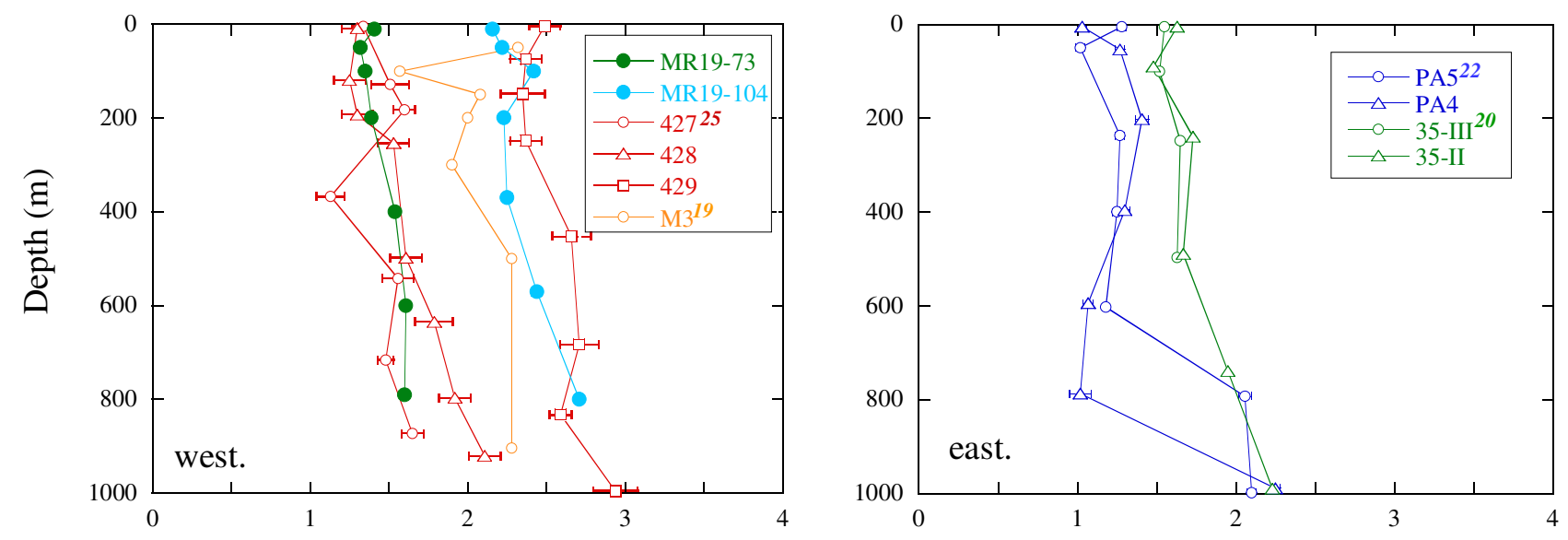

Southern Ocean
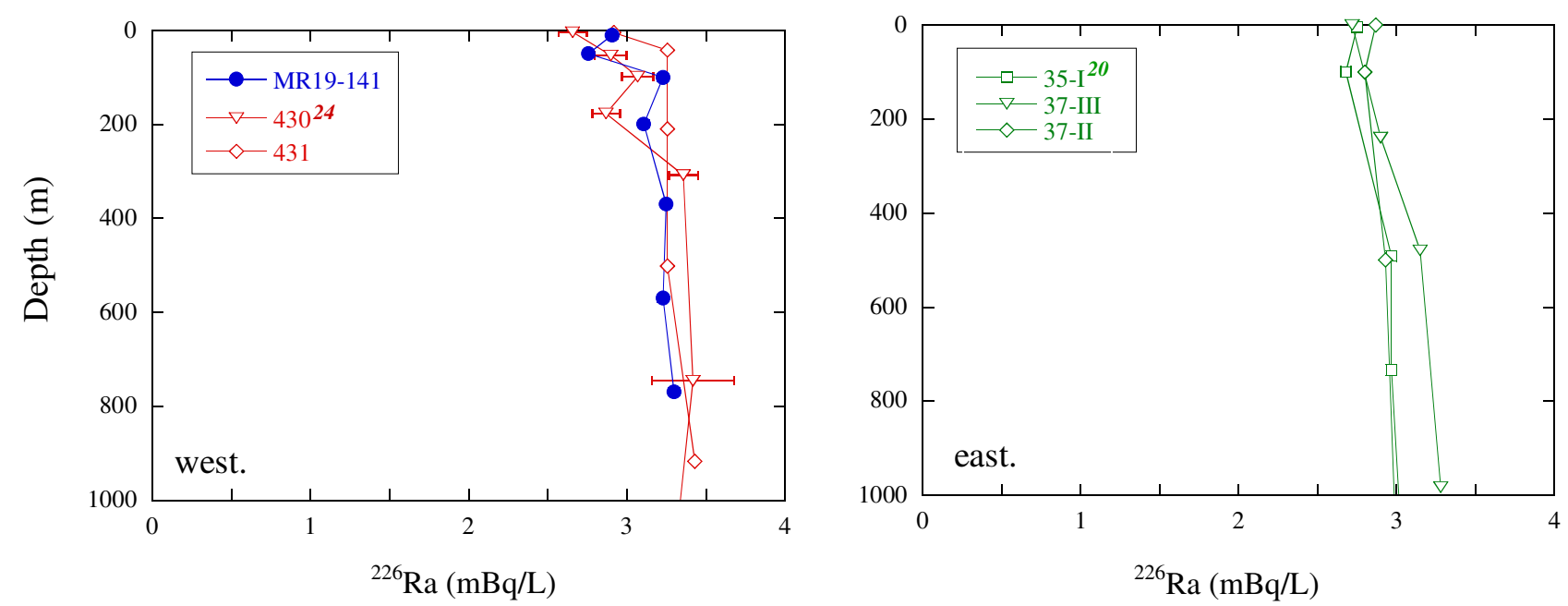

Figure 3. Vertical profiles of ${ }^{226} \mathrm{Ra}$ concentrations in the western (west.; $<90^{\circ} \mathrm{E}$ ) and eastern sections (east.; $>90^{\circ} \mathrm{E}$ ) in the monsoon-subtropical (northern side of $\sim 20^{\circ} \mathrm{S}$ ) and subantarctic $\left(20-60^{\circ} \mathrm{S}\right)$ areas in the Indian Ocean and the Southern Ocean (southern side of $\sim 60^{\circ} \mathrm{S}$ ), along with data from previous studies in each $\operatorname{area}^{19,20,22,24,25}$.

(Fig. 6), indicate less mixing of low-density and low- ${ }^{226} \mathrm{Ra}$ currents, relative to that in the eastern area. High ${ }^{226} \mathrm{Ra}$ concentrations at site MR19-141 could have been caused by a greater contribution from the ${ }^{226} \mathrm{Ra}$-rich ACC. 

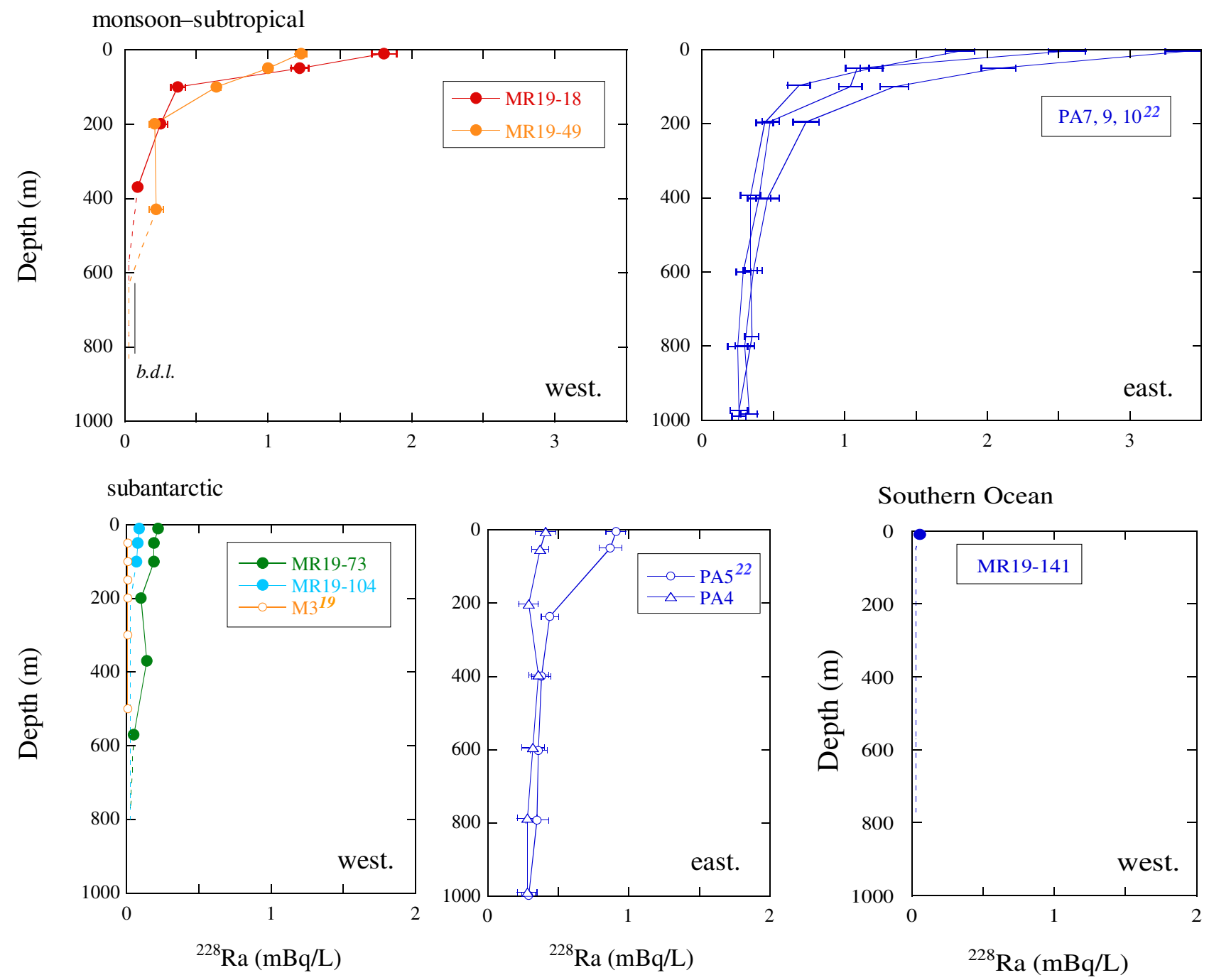

Figure 4. Vertical profiles of ${ }^{228} \mathrm{Ra}$ concentrations in the monsoon-subtropical and subantarctic areas in the Indian Ocean and the Southern Ocean, along with data from previous studies in each area ${ }^{19,22}$.

The ${ }^{226} \mathrm{Ra}$ inventory at site $431\left(2638 \mathrm{~Bq} / \mathrm{m}^{2}\right)$ exhibited the highest value in this study area ${ }^{24}$. Conversely, the ${ }^{226} \mathrm{Ra}$ concentrations above a depth of $800 \mathrm{~m}$ at site PA4 were equivalent to the lowest values recorded in the Indian Ocean, such as the upper layer in the northern Indian Ocean (Fig. 3). Therefore, we considered the water columns from depths of 0 to $800 \mathrm{~m}$ at sites 431 and PA4 $\left(970 \mathrm{~Bq} / \mathrm{m}^{2}\right)$ as the end-members in the ACC and the water from the northern Indian Ocean, respectively. Consequently, the fractions of the ACC (i.e., column waters at site 431) were estimated as 0.95 at MR19-141, 0.56 at MR19-104, 0.14 at MR19-73, and 0.44 at site M3, based on their inventories (Fig. 7). The fractions at sites EL35-II and -III in the eastern Indian Ocean (0.27 and 0.39, respectively) correspond to $\sim 60 \%$ of that at site MR19-104, despite their similar latitude. Higher inventories in the western subantarctic Indian Ocean could be explained by the direct inflow of the ACC, compared to that in the eastern area, where the ACC has longer pathways $(<10$ and $<30$ years to the west and east, respectively, based on CFC age $)^{7,31}$, and by the large-scale intrusion of southward currents observed offshore of western Australia ${ }^{22}$.

Decadal variations in seawater temperature have recently been recorded in and around the polar front, reflecting changes in global climate ${ }^{11}$. Anomalous warming below depths of $200 \mathrm{~m}$ is accompanied by density anomalies in the Southern Ocean ${ }^{41,42}$. The fraction at site MR19-141 was comparable to that at the closest site 430 $\left(2593 \mathrm{~Bq} / \mathrm{m}^{2}, 0.97\right)$. Additionally, the ACC fractions at sites MR19-104 and -73 exhibited similar values to those observed at sites $429(0.64)$ and $428-427(0.17-0.11)$ in $1978^{25}$. This can be primarily attributed to the minimal effects of the southward shift of the polar front ${ }^{10}$ and/or the short-term (e.g., annual) and local variations in the circulation of the ACC-dominated water ${ }^{43}$ and eddy mixing ${ }^{44}$. Compared to earlier reports, our study of water currents using ${ }^{226} \mathrm{Ra}$ and ${ }^{228} \mathrm{Ra}$ did not indicate any significant decrease in the contribution of the ACC that could be attributed to the southward shift of the polar front due to global warming since the 1970s. 

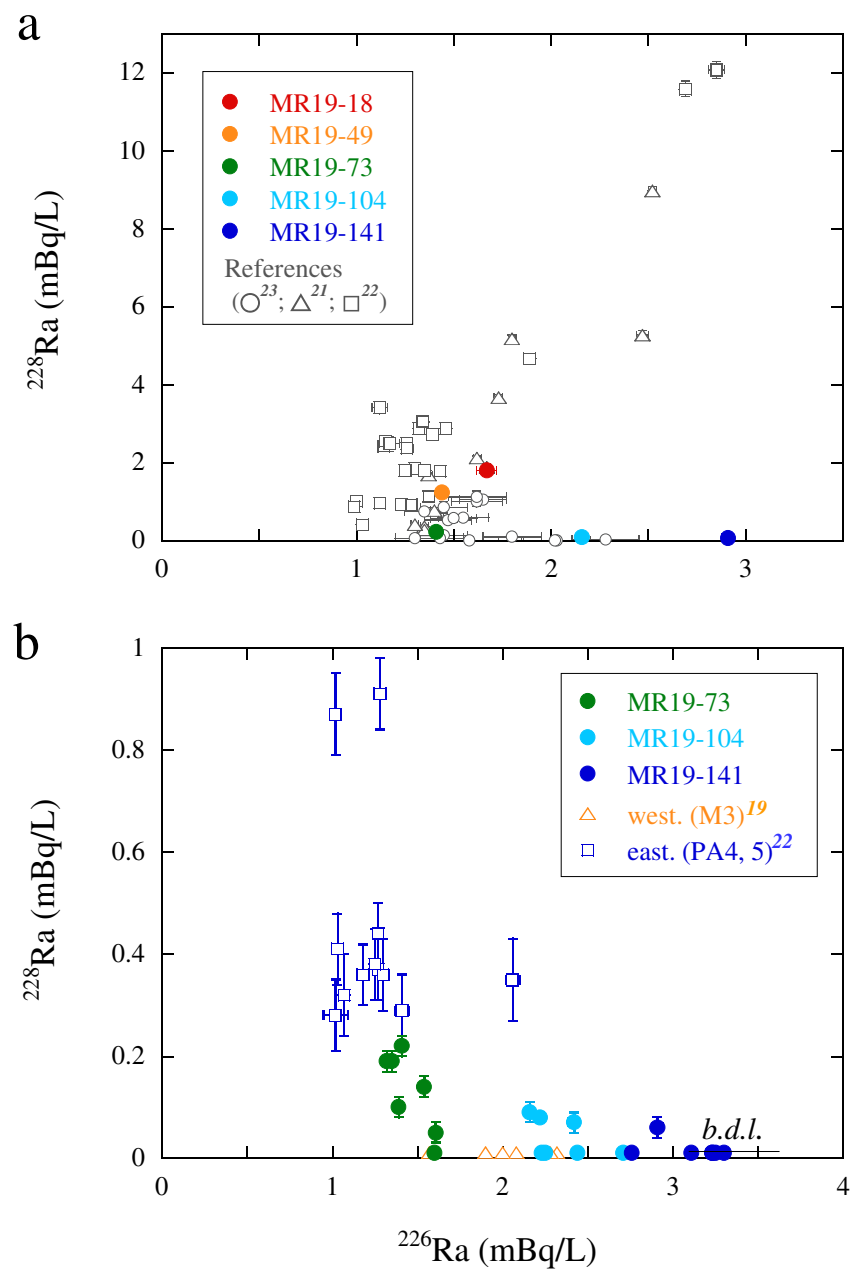

Figure 5. ${ }^{226} \mathrm{Ra}$ versus ${ }^{228} \mathrm{Ra}$ concentrations of waters from (a) the surface (depth $\leq 10 \mathrm{~m}$ ) and (b) surface to a depth of $800 \mathrm{~m}$, along with data from previous studies in the Indian and Southern Oceans $\mathrm{s}^{1,21-23}$.

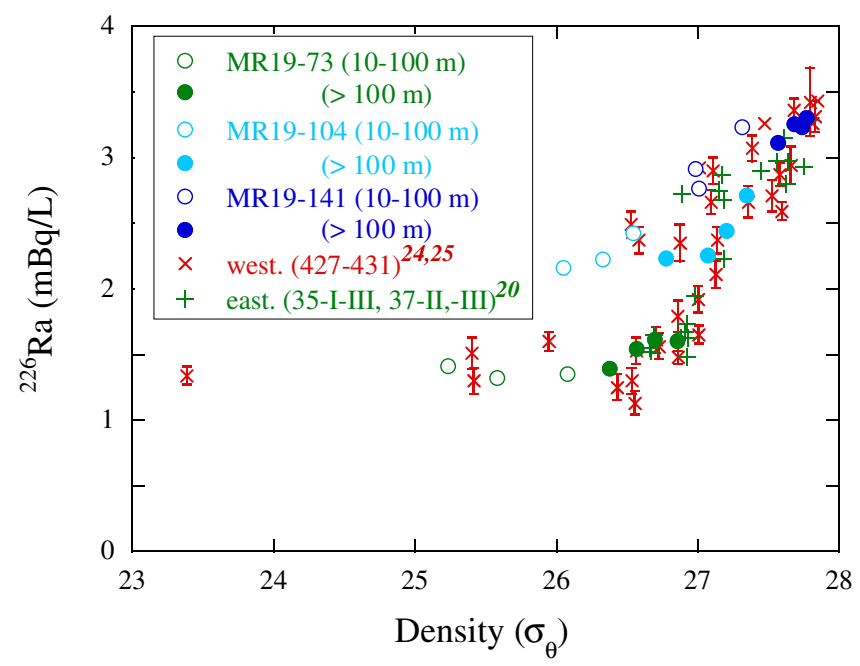

Figure 6. ${ }^{226} \mathrm{Ra}$ concentrations versus potential density of waters from the surface to a depth of $800 \mathrm{~m}$, along with data from previous studies in the Indian and Southern Oceans ${ }^{20,24,25}$. 


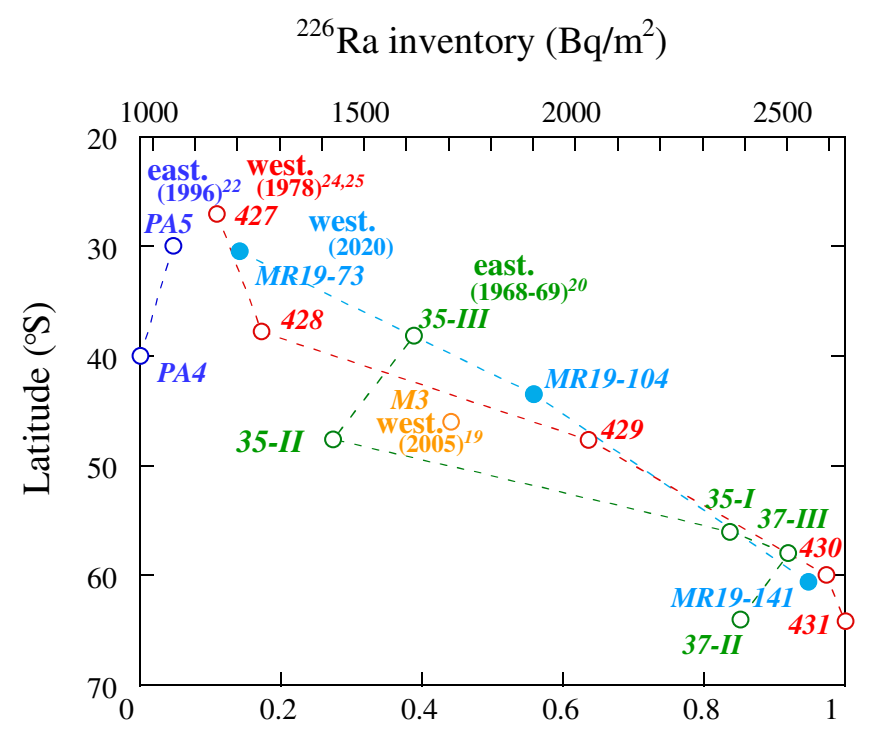

Fraction of ACC

Figure 7. Inventories of ${ }^{226} \mathrm{Ra}$ concentrations (depth of $0-800 \mathrm{~m}$ ) and fractions of the ACC (1.0 at site 431) versus latitude, compared with data from previous studies recorded in the western ${ }^{19,24,25}$ and eastern Sections ${ }^{20,22}$ of the subantarctic Indian and Southern Oceans over the last 50 years.

\section{Methods}

Seawater samples and experiments. A total of 35 seawater samples $(\sim 40 \mathrm{~L}$ each $)$ were collected at depths of 10-830 $\mathrm{m}$ from five water columns in the Indian and Southern Oceans using a conductivity-temperature-depth rosette with 36 Niskin-X bottles (12 L) during the R/V Mirai expedition from December 2019 to January 2020 (MR19-04 expedition) (Fig. 1a). All water samples were unfiltered. The experimental procedures employed to collect $\mathrm{Ra}$ in seawater samples have been previously described ${ }^{45}$. After adjusting the $\mathrm{pH}$ to $\sim 1 \mathrm{using}$ concentrated $\mathrm{HNO}_{3}$, a minimally Ra-contaminated Ba carrier $(960 \mathrm{mg})$ was added to a $\sim 40 \mathrm{~L}$ aliquot of each seawater sample, and $\mathrm{BaSO}_{4}$ was precipitated with the $\mathrm{Ra}$ isotopes. The chemical yields of the $\mathrm{Ra}$ isotopes were 93-100\%, based on the yields of the $\mathrm{BaSO}_{4}$ fractions.

Low-background $\gamma$-spectrometry was performed on all $\mathrm{BaSO}_{4}$ samples using high-purity Ge-detectors located in the Ogoya Underground Laboratory, Japan ${ }^{46}$, over 3-5 counting days. The ${ }^{226} \mathrm{Ra}$ concentrations were evaluated from the $\gamma$-ray peaks of ${ }^{214} \mathrm{~Pb}(295$ and $352 \mathrm{keV})$ after reaching radioactive equilibrium ( $>3$ weeks after sample compression); they were calibrated from the peak ratios of mock-up samples with almost the same chemical composition as the water samples, including uranium standards issued by the New Brunswick Laboratory, USA (NBL-42-1). In addition, ${ }^{228} \mathrm{Ra}$ concentrations were characterized from ${ }^{228} \mathrm{Ac}$ (338 and $911 \mathrm{keV}$ ), based on the detection efficiency curve obtained from the mock-up samples.

Under the analytical conditions employed in this study, the minimum amount of ${ }^{228} \mathrm{Ra}$ that could be determined in a water sample was $\sim 1.5 \mathrm{mBq}$. This corresponded to a detection limit of $\sim 0.03 \mathrm{mBq} / \mathrm{L}$ when using $\sim 40$ $\mathrm{L}$ of sampled seawater. Based on the standard deviation, the analytical precision was $1-3 \%$ and $3-30 \%$ for ${ }^{226} \mathrm{Ra}$ and ${ }^{228} \mathrm{Ra}$, respectively. Both the ${ }^{228} \mathrm{Ra}$ and ${ }^{226} \mathrm{Ra}$ concentrations in this study were decay-corrected to the sampling date.

Received: 7 September 2021; Accepted: 18 January 2022

Published online: 02 February 2022

\section{References}

1. Orsi, A. H., Whitworth, T. I. I. I. \& Nowlin, W. D. Jr. On the meridional extent and fronts of the Antarctic circumpolar current. Deep-Sea Res. I 42, 641-673 (1995).

2. Talley, L. D. Freshwater transport estimates and the global overturning circulation: Shallow, deep and throughflow components. Prog. Oceanogr. 78, 257-303 (2008).

3. Talley, L. D. Southern Ocean. In Descriptive Physical Oceanography 6th edn (eds Talley, L. D. et al.) 437-471 (Elsevier, 2011).

4. You, Y. \& Tomczak, M. Thermocline circulation and ventilation in the Indian Ocean derived from water mass analysis. Deep-Sea Res. I 40, 13-56 (1993).

5. You, Y. Implications of the deep circulation and ventilation of the Indian Ocean on the renewal mechanism of North Atlantic Deep Water. J. Geophys. Res. 105(C10), 23895-23926 (2000).

6. Talley, L. D. Indian Ocean. In Descriptive physical oceanography 6th edn (eds Talley, L. D. et al.) 363-399 (Elsevier, 2011).

7. Fine, R. A. Circulation of Antarctic intermediate water in the South Indian Ocean. Deep-Sea Res. I 40, 2021-2042 (1993).

8. Park, Y.-H. \& Gamberoni, L. Cross-frontal exchange of Antarctic intermediate water and Antarctic bottom water in the Crozet Basin. Deep-Sea Res. II 44, 963-986 (1997). 
9. Pollard, R. T., Lucas, M. I. \& Read, J. F. Physical controls on biogeochemical zonation in the Southern Ocean. Deep-Sea Res. II 49, 3289-3305 (2002).

10. Fyfe, J. C. \& Saenko, O. A. Simulated changes in the extratropical Southern Hemisphere winds and currents. Geophys. Res. Lett. 33, L06701 (2006).

11. Freeman, N. M., Lovenduski, N. S. \& Gent, P. R. Temporal variability in the Antarctic Polar Front (2002-2014). J. Geophys. Res. Oceans 121, 7263-7276 (2016).

12. Povinec, P. P. et al. Spatial distribution of ${ }^{3} \mathrm{H},{ }^{90} \mathrm{Sr},{ }^{137} \mathrm{Cs}$ and ${ }^{239,240} \mathrm{Pu}$ in surface waters of the Pacific and Indian Oceans-GLOMARD database. J. Environ. Radioactivity 76, 113-137 (2004).

13. Lachkar, Z., Orr, J. C., Dutay, J.-C. \& Delecluse, P. On the role of mesoscale eddies in the ventilation of Antarctic intermediate water. Deep-Sea Res. I 56, 909-925 (2009).

14. Kumamoto, Y., Murata, A., Watanabe, S. \& Fukasawa, M. Temporal and spatial variations in bomb-produced radiocarbon along BEAGLE2003 lines-Revisits of WHP P06, A10, and I03/I04 in the Southern Hemisphere Oceans. Prog. Oceanogr. 89, 49-60 (2011).

15. Ku, T.-L., Huh, C. A. \& Chen, P. S. Meridional distribution of ${ }^{226}$ Ra in the Eastern Pacific along Geosecs Cruise Tracks. Earth Planet. Sci. Lett. 49, 293-308 (1980).

16. Inoue, M. et al. Vertical profiles of ${ }^{228} \mathrm{Ra}$ and ${ }^{226} \mathrm{Ra}$ activities in the Sea of Japan and their implications on water circulation. J. Radioanal. Nucl. Chem. 303, 1309-1312 (2015).

17. Inoue, M. Surface distribution of ${ }^{228} \mathrm{Ra}$ in and around the Sea of Japan: Implications for water migration and delivery of soluble contaminants. in Trans-Boundary Pollution in North-East Asia 261-278 (Nova Science Publishers, 2018).

18. Inoue, M. et al. Lateral variations of ${ }^{134} \mathrm{Cs}$ and ${ }^{228} \mathrm{Ra}$ concentrations in surface waters in the western North Pacific and its marginal sea (2018-2019): Implications for basin-scale and local current circulations. Prog. Oceanogr. 195, 102587 (2021).

19. Charette, M. A. et al. Radium isotopes as tracers of iron sources fueling a Southern Ocean phytoplankton bloom. Deep-Sea Res. II 54, 1989-1998 (2007).

20. Ku, T.-L., Li, Y. H., Mathieu, G. G. \& Wong, H. K. Radium in the Indian-Antarctic Ocean south of Australia. J. Geophys. Res. 75, 5286-5292(1970).

21. Nozaki, Y., Dobashi, F., Kato, Y. \& Yamamoto, Y. Distribution of Ra isotopes and the ${ }^{210} \mathrm{~Pb}$ and ${ }^{210} \mathrm{Po}$ balance in surface seawaters of the mid Northern Hemisphere. Deep-Sea Res. I 45, 1263-1284 (1998).

22. Nozaki, Y. \& Yamamoto, Y. Radium 228 based nitrate fluxes in the eastern Indian Ocean and the South China Sea and a siliconinduced "alkalinity pump" hypothesis. Glob. Biogeochem. Cycles 15, 555-567 (2001).

23. Okubo, T., Furuyama, K. \& Sakanoue, M. Distribution of ${ }^{228} \mathrm{Ra}$ in surface sea water of the East Indian Ocean. Geochem. J. 13, 201-206 (1979)

24. Chung, $\mathrm{Y} .{ }^{210} \mathrm{~Pb}$ and ${ }^{226} \mathrm{Ra}$ distributions in the Circumpolar waters. Earth Planet. Sci. Lett. 55, 205-216 (1981).

25. Chung, Y. ${ }^{226} \mathrm{Ra}$ in the western Indian Ocean. Earth Planet. Sci. Lett. 85, 11-27 (1987).

26. Moore, W. S. \& Santschi, P. H. Ra-228 in the deep Indian Ocean. Deep-Sea Res. 33, 107-120 (1986).

27. Kumar, M. D. \& Li, Y.-H. Spreading of water masses and regeneration of silica and ${ }^{226} \mathrm{Ra}$ in the Indian Ocean. Deep-Sea Res. II 43 , 83-110 (1996).

28. Ku, T.-L. \& Lin, M.-C. ${ }^{226}$ Ra distribution in the Antarctic Ocean. Earth Planet. Sci. Lett. 32, 236-248 (1976).

29. JAMSTEC. WHP I08N Revisit/I07S in 2019/2020 Data Book (eds. Uchida, H., Murata, A., Katsumata, K., \& Arulananthan, Doi, T.). https://doi.org/10.17596/0002162 (2020)

30. Park, Y.-H., Gamberoni, L. \& Charriaud, E. Frontal structure and transport of the Antarctic Circumpolar Current in the south Indian Ocean sector, $40-80^{\circ}$ E. Mar. Chem. 35, 45-62 (1991).

31. Herraiz-Borreguero, L. \& Rintoul, S. R. Subantarctic mode water: Distribution and circulation. Ocean Dyn. 61, 103-126 (2011).

32. Nozaki, Y., Tsubota, H., Kasemsupaya, V., Yashima, M. \& Ikuta, N. Residence time of surface water and particle-reactive ${ }^{210} \mathrm{~Pb}$ and ${ }^{210}$ Po in the East China and Yellow seas. Geochim. Cosmochim. Acta 55, 1265-1272 (1991).

33. Inoue, M. et al. Migration area of the Tsushima Warm Current Branches within the Sea of Japan: Implications from transport of ${ }^{228}$ Ra. Cont. Shelf Res. 143, 167-174 (2017).

34. Shankar, D., Vinayachandran, P. N. \& Unnikrishnan, A. S. The monsoon currents in the north Indian Ocean. Prog. Oceanogr. 52, 63-120 (2002).

35. Inoue, M. et al. Distributions of radiocesium and radium isotopes in the western Bering Sea in 2018. Mar. Chem. 225, 103843 (2020).

36. Chung, Y.-C. Radium-226 and Ra-Ba relationships in Antarctic and Pacific waters. Earth Planet. Sci. Lett. 23, 125-135 (1974).

37. Rutgers Van Der Loeff, M. M.. ${ }^{228}$ Ra and ${ }^{228}$ Th in the Weddell Sea. in The Polar Oceans and Their Role in Shaping the Global Environment 177-186 (American Geophysical Union, 1994).

38. Rutgers Van Der Loeff, M. M. \& Berger, G. W. Scavenging of ${ }^{230} \mathrm{Th}$ and ${ }^{231} \mathrm{~Pa}$ near the Antarctic Front in the South Atlantic. DeepSea Res. I 40, 339-357 (1993).

39. He, Y., Wang, H. \& Liu, Z. Development of the Leeuwin Current on the northwest shelf of Australia through the Pliocene-Pleistocene period. Earth Planet. Sci. Lett. 559, 116767 (2021).

40. GEOSECS. Atlantic, Pacific, and Indian Ocean Expeditions; Vol. 7 Shorebased Data and Graphics (National Science Foundation, 1987).

41. White, W. B. \& Peterson, R. G. An Antarctic circumpolar wave in surface pressure, wind, temperature and sea-ice extent. Nature 380, 699-702 (1996).

42. Morioka, Y., Taguchi, B. \& Behera, S. K. Eastward propagating decadal temperature variability in the South Atlantic and Indian Oceans. J. Geophys Res. Oceans 122, 5611-5623 (2017).

43. Kim, Y. S. \& Orsi, A. H. On the variability of Antarctic Circumpolar Current Front inferred from 1992-2011 altimetry. J. Phys. Oceanogr. 44, 3054-3071 (2014).

44. Naveira-Garabato, A. C., Ferrari, R. \& Polzin, K. L. Eddy stirring in the Southern Ocean. J. Geophys. Res. Oceans 116, C09019 (2011).

45. Nakano, Y., Inoue, M. \& Komura, K. A simple coprecipitation method combined with low-background $\gamma$-spectrometry: Determination of ${ }^{7} \mathrm{Be},{ }^{137} \mathrm{Cs},{ }^{210} \mathrm{~Pb}$, and radium and thorium isotopes in small-volume coastal water samples. J. Oceanogr. 64, 713-717 (2008).

46. Hamajima, Y. \& Komura, K. Background components of Ge detectors in Ogoya underground laboratory. Appl. Radiat. Isot. 61, 179-183 (2004).

\section{Acknowledgements}

We are grateful to the researchers, captain, and crew onboard the R/V Mirai for their assistance during sampling. This research was partly supported by the Japan Society for the Promotion of Science (JSPS) KAKENHI (Grant No. JP18K11615). 


\section{Author contributions}

M.I. wrote the paper. S.H. and H.K. performed the radium measurements. Y.K. designed the study and led the cruise. S.N. supervised the project.

\section{Competing interests}

The authors declare no competing interests.

\section{Additional information}

Correspondence and requests for materials should be addressed to M.I.

Reprints and permissions information is available at www.nature.com/reprints.

Publisher's note Springer Nature remains neutral with regard to jurisdictional claims in published maps and institutional affiliations.

(c) (i) Open Access This article is licensed under a Creative Commons Attribution 4.0 International License, which permits use, sharing, adaptation, distribution and reproduction in any medium or format, as long as you give appropriate credit to the original author(s) and the source, provide a link to the Creative Commons licence, and indicate if changes were made. The images or other third party material in this article are included in the article's Creative Commons licence, unless indicated otherwise in a credit line to the material. If material is not included in the article's Creative Commons licence and your intended use is not permitted by statutory regulation or exceeds the permitted use, you will need to obtain permission directly from the copyright holder. To view a copy of this licence, visit http://creativecommons.org/licenses/by/4.0/.

(C) The Author(s) 2022 